\title{
Development of Powerpoint-Based Multimedia for Elementary School Teachers
}

\author{
Azizah Hayati ${ }^{1}$, Ristiana Dyah Purwandari ${ }^{2}$ \\ \{azizahhayati.mai@gmail.com ${ }^{1}$, ristianadyah@yahoo.com² ${ }^{2}$,
}

Elementary School 2 Bojanegara ${ }^{1}$, Elementary School Teacher Study Program, Universitas Muhammadiyah Purwokerto ${ }^{2}$

\begin{abstract}
This article discusses the creativity of teachers in making thematic science teaching materials. This article aims to know that teacher creativity can be developed through training so that teachers can create thematic science teaching materials. This research aims to develop teachers' creativity in creating science thematic teaching materials through training through the Microsoft PowerPoint app. The method of writing this scientific work is to use Research and Development (RnD). Creativity consists of two dimensions, namely cognitive (creative thinking), affective (creative attitude). Creative thinking includes fluency, flexibility, originality, elaboration, and evaluation. Creative attitudes include openness, flexibility in attitude, freedom in self-expression, appreciating fantasy, interest in creative activities, belief in ideas themselves, self-reliance in giving consideration. While creative (psychomotor) skills include determining creative challenges, identifying information sources, developing and selecting ideas, presenting product results, and authenticity. Related to the creativity of teachers, teachers are expected to make thematic materials of science. Science thematic teaching materials are all forms of materials used to assist teachers or instructors in carrying out teaching and learning activities in the classroom in the form of written or unwritten materials that focus on science learning to grow students' abilities in an incanity and contains anyway according to real life. Developing teacher creativity training can train teachers in making science thematic teaching materials that benefit teachers and appeal to students.
\end{abstract}

Keywords: Creativity, Teacher, Teaching Materials, Science Thematic, Training

\section{Introduction}

The development of human life, the development of problems faced by education, increasingly demands human progress in thinking about education. Now it is increasingly realized that education plays an essential role in the life and progress of humanity. [2]Education is a human effort to build his personality following the values in society and culture. One of the roles of a teacher with competence that he has, is the transfer of knowledge and agent of change. A teacher must always be responsive to the situation, responsive to the latest news and discourses. Teachers should also make teaching materials and know the applications that support in carrying out teaching and learning activities.

Based on observations and interviews, this situation becomes a problem for teachers at SDN 2 Bojanegara. Some teachers are not ready to conduct modern learning and are always related to information and communication technology, one of the educational progress conditions. Especially during the Covid19, teachers find it challenging to provide learning because they cannot come face-to-face with students directly. 
Teachers' ability to master technology seems to be challenged when students and teachers are no longer able to meet face to face. Teachers should also be able to satisfy parents as customers of educational services. Therefore, it is necessary to develop teacher professionalism to be sustainable to maintain and improve teacher creativity, including activities designed to improve teacher skills, understanding and skills with the help of advanced technology with applications that are developing today, applications used are available in each laptop or computer and handphone so that teachers can make creative teaching materials.

Creating and editing software selection for teachers in Simo, P., Fernandez, V., et al. (2010), to achieve a minimum degree of autonomy in elaborating dynamic teaching materials themselves, is part of ongoing training and is, therefore, a key element in improving selfteaching. So videos that are added written explanations related to audiovisual content are excellent teaching materials, as they provide a clear and complete picture of a particular event or process. Creating short, low-cost educational videos allows re-use in other pieces of training and creating your videos made.

Based on the above problems and considerations, research is needed to develop teacher creativity in teaching materials. It is accommodated in educational and training activities for teachers entitled "Developing teacher creativity training in making science thematic teaching materials through Microsoft PowerPoint application in Elemetary School." The development of this creativity training will consist of a program design in training for elementary school teachers with more emphasis. Elementaryers' creativity in making teaching materials with the help of technology/application that develops, teaching materials that will be made in the form of learning videos.

\section{Method}

The research method used is research development, namely Research and Development $(\mathrm{RnD})$, with its development in the form of training programs to make thematic teaching materials of science to develop elementary school teachers' creativity. The development model used refers to the ADDIE (Analysis, Design, Development, Implementation, and Evaluation) model developed by Robert Maribe Branch. Addie model is one of the systematic learning design models with steps used more simply, clearly, and has been widely used in previous research. This model consists of five steps, namely: analyze, design, development, implementation, and evaluation. The steps of the ADDIE model can be seen in the following figure: 


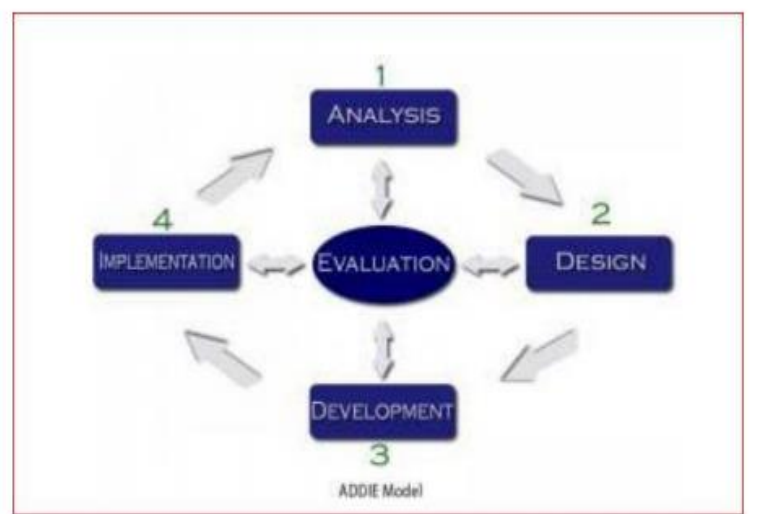

Fig 1. Development Measures according to Dick and Carry model ADDIE

The development procedure in this research uses the ADDIE model stage developed by Robert Maribe Branch. The ADDIE model was developed to design a systematic, simple, and transparent learning system. Development steps as follows (Sugiyono, 2016: 38-39):

- Analyze is related to the analysis of the working environment situation to find what development will be done.

- Design is the stage of designing activities to be carried out. The design is still conceptual and will underpin the next development process. The design stage is focused on three activities: material selection following the demands of creative competencies to be achieved, development strategies, forms, and assessment and evaluation methods.

- Development is at the stage of development carried out several activities: searching and gathering various relevant sources to enrich materials, making teaching materials, training on teachers, charts and graphics needed, typing, editing, and storage in the form of learning videos. The following activities in the development stage are activities to validate the draft product development and revision after experts' input.

- Implementation is the activity of using products. At this stage, the development results are applied to improve teacher creativity in making thematic teaching materials of science.

- Evaluation is an activity to assess whether each step of activities and products that have been made is following the specifications or not. The evaluation results are used to provide feedback to the user, and revisions are made following the evaluation results or needs that have not been met in developing the teacher's creativity.

A research site is a research place for researchers at SDN 2 Bojanegara, Padamara Subdistrict, Purbalingga Regency. The research subjects involved teachers at SDN 2 Bojanegara, grade 1 teachers, grade II teachers, grade III teachers, two grade 4 teachers, two grade V teachers, grade 6 teachers, Islamic Religious Education teachers, and Sports Physical Education teachers of 1 person each. 
1. Teachers at SDN 2 Bojanegara, filling out questionnaires and initial interviews involving teachers at SDN 2 Bojanegara. Teachers at SDN 2 Bojanegara filled out questionnaires and interview guidelines.

2. Measurement of teacher creativity is done in science thematic teaching materials training through Microsoft PowerPoint application. The subjects of the next phase of the study included the validator, principal of SDN 2 Bojanegara.

The research instruments used are questionnaires, interviews, observation guidelines, Measurement sheet of teacher's creative thinking skills, measurement sheet of teacher's creative attitude. The teacher's creative thinking skills sheet was adapted from Purwandari (2018), and the teacher's creative attitude measurement sheet was adapted from the Creativity Attitude Survey by Carles E. Schaefer, Ph.D., Fordham University (Munandar, 1999).

Assessment of teachers' creative thinking skills by validators using this type of Likert scale. This Likert scale is arranged in the form of a statement and followed by four responses that will indicate the level, which includes:

Tabulation of all data obtained for each aspect of the assessment item available in the assessment instrument.Calculate the average total score of each aspect by using the Sudjana formula (2009: 109)

$$
\begin{aligned}
& \bar{X}=\sum_{i}^{n} X_{i} \\
& \bar{X} \quad=\text { Average value } \\
& \sum_{i}^{n} X_{i}=\text { Sum of values obtained. } \\
& \mathrm{n} \quad=\text { number of statement items }
\end{aligned}
$$

The preparation of scoring guidelines is with the number of items 20 statements, using four scales, then the maximum score of 80 and a score of at least 20 . The calculation formula of the range is as follows:

Scale range $\quad=\frac{\text { highest score-lowest score }}{\text { number of interval classes }}$

Converts the average score of each aspect obtained into qualitative based on four scale assessment criteria. For conversion, the practicality assessment score is obtained by calculating the interval from 1 to 4 , which is 0.75 . After that, the score obtained in the conversion into qualitative data as in Table 1.

Table 1. Conversion of Quantitative Data Score into Qualitative Data

\begin{tabular}{|c|c|}
\hline Average & Criteria \\
\hline $1,00<\underline{X}<1,75$ & Less Creative Thinking \\
\hline $1,75<\underline{X}<2,50$ & Enough Creative Thinking \\
\hline $2,50<\underline{X}<3,25$ & Good Creative Thinking \\
\hline $3,25<\underline{X}<4,00$ & Very Well Creative Thinking \\
\hline
\end{tabular}

Source: Sudjana (2009: 109) modified researcher

Teacher Creative Attitude Analysis, assessment of teacher's creative attitude by validator using Likert scale type. This Likert scale is arranged in the form of a statement and followed by four responses that will indicate the level, which includes: 
Tabulation of all data obtained for each aspect of the assessment item available in the assessment instrument. Calculate the average total score of each aspect by using the Sudjana formula (2009: 109) using formula (1). The preparation of scoring guidelines is with the number of items 20 statements, using four scales, then the maximum score of 80 and a score of at least 20. The calculation formula of the range is as follows:

Scale range $\quad=\frac{\text { highest score-lowest score }}{\text { number of interval classes }}$

Converts the average score of each aspect obtained into qualitative based on four scale assessment criteria. For conversion, the practicality assessment score is obtained by calculating the interval from 1 to 4 , which is 0.75 . After that, the score obtained in the conversion into qualitative data as in Table 2.

Table 2. Conversion of Quantitative Data Score into Qualitative Data

\begin{tabular}{|c|c|}
\hline Average & Criteria \\
\hline $1,00<\underline{X}<1,75$ & Less Creative Attitude \\
\hline $1,75<\underline{X}<2,50$ & Enough Creative Attitude \\
\hline $2,50<\underline{X}<3,25$ & Good Creative Attitude \\
\hline $3,25<\underline{X}<4,00$ & Very Well Creative Attitude \\
\hline
\end{tabular}

Source: Sudjana (2009: 109) modified researcher

\section{Results and Discussion}

This research is a Research and Development $(\mathrm{RnD})$ research with its development in training programs to make thematic teaching materials of science to develop the creativity of elementary school teachers. The development model used refers to the ADDIE (Analysis, Design, Development, Implementation, and Evaluation) model developed by Robert Maribe Branch. The stages carried out in the training program make thematic teaching materials of science to develop the creativity of elementary school teachers. The first stage is the analysis stage (Analyze) is carried out a procedure used to foster teacher creativity. Based on the analysis of needs obtained through observation, the result is that creative thinking, creative attitudes, and teachers' creative skills have not been fully supportive of teaching materials. Therefore, the first stage of analysis is carried out in training by displaying examples of teaching materials in interesting learning videos for teachers to make.

The design stage is carried out the preparation of teaching materials that produce drafts, teachers draft drafting teaching materials according to the video of learning that has been displayed and teaching materials. The draft is tailored to the classes that each teacher has mastered or according to their respective fields of study. The development stage is carried out by mentoring to make teaching materials in learning videos carried out by researchers. Teachers are guided to create learning videos through the Microsoft PowerPoint app. Steps taken 1) introduction of Microsoft PowerPoint applications and tools and features contained in PowerPoint, 2) steps to create teaching materials using engaging powerpoints, such as (a) selection of exciting templates that can be obtained by downloading for free on google (b) how to crop learning materials from the teacher's book (c) utilization of shapes, colors, animations, and design features, and (d) inserting images/videos (e) hyperlinks, 3) Utilization of notes on PowerPoint to assist in the process of recording audio, 4) the process of recording audio (dubbing sound) and 5) the process of converting PowerPoint media into learning videos. In 
addition to material exposure and direct practice, this stage is also followed by question and answer sessions and discussions to find out the level of understanding of participants in this activity.

There are steps in making teaching materials in the form of learning videos are as follows:

1. They were preparing teaching materials or teaching materials that are already available in the BSE Teacher's Book. All trainees must prepare teaching materials referring to the RPP already owned by the participants. And in this exercise, participants were asked to complete learning materials for one meeting as a suitable material.

2. Design background teaching materials in Microsoft PowerPoint to make them more attractive. After the participants crop the material and then insert it into the slides until it is finished, the participant is directed to include images and videos that are interesting and relevant to the material's theme to be used as the background or background of the material. This aims to make the display of teaching materials more enjoyable to be read by the learners.

3. Utilization of notes on PowerPoint to assist in the audio recording process

Step three, the teacher/participant writes what will be delivered in the learning video, for example

Narrative:

1) Say hello

2) Remind pray before learning

3) This time with me ..... We'll learn about....

4. Audio recording process (dubbing sound)

Step four, audio recording should be in a quiet place or use a mic for mobile phones that are now widely traded - Proses merubah media PowerPoint menjadi video pembelajaran.

5. The fifth step is to convert the typed and designed material in ppt format into mp4 form.

Implementation stage, to find out the improvement of teacher creativity in making thematic teaching materials of science. Based on the questionnaire/questionnaire of teachers' creative thinking skills and the trial implementation results, I obtained an average of 2.42 included in the criteria enough. In the implementation of trial I, the average teacher has not added various materials to the teaching materials, has not given new ideas in making teaching materials, only following the directions given, just following the idea that has been given. At the same time, the questionnaire/questionnaire test of the teacher's creative attitude, the results of the first trial's implementation obtained the average creative attitude of teachers 3.1 with the right criteria because the teacher has been able to make his teaching materials still feel hesitant. The teacher has a desire to make teaching materials that are useful for learners. During the training, the teacher was enthusiastic about making ajat material because he wanted to get better learning ideas than before.

After the first trial, the teacher was guided again in teaching materials in learning videos that are more following the teaching materials and specifications of teacher creativity more complete than before with trial II. After the evaluation stage is completed, training/training teacher creativity can be resumed on a wide scale. Analysis of teachers' creative thinking skills in creating science thematic teaching materials through Microsoft PowerPoint applications on the development of teacher creativity training. In creative thinking skills, teachers' activities are based on questionnaires/questionnaires that have been distributed to teachers or trainees. This observation and research activity concerns teacher creativity training development in the first and second trial stages. The tables and histograms on teachers' creative thinking skills are as follows: 
Table 3. Observation Results of Teacher's Creative Thinking Skills

\begin{tabular}{|c|c|c|}
\hline \multirow{2}{*}{ Trial } & Average Trial & Criteria \\
& & \\
\hline I & 2,42 & Enough Creative Thinking \\
\hline II & 3,14 & Good Creative Thinking \\
\hline Increased & 0,72 & \\
\hline
\end{tabular}

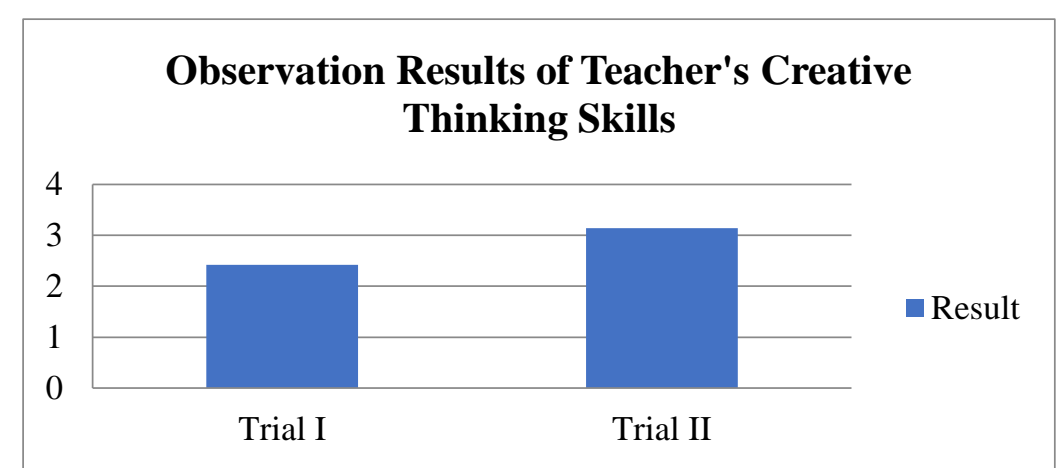

Fig 1. Histogram Observation Of Teacher's Creative Thinking Skills

Based on Table 3 and Fig 1 above, the teacher's creative thinking skills improved on average on each trial I trial II indicator. Teacher creativity development training during the first trial has enough criteria. This result is known with a total score of 206, with an average of 2.42. According to the results in this I trial, it turns out that the teacher's creative thinking skills are still included in the criteria enough. This can be seen from the teacher still making teaching materials that are following the example researchers. Teachers still have difficulty in making teaching materials in the form of interactive videos. In the second trial, the teacher made impressive teaching materials following the ideas/teaching materials. The observation of teachers' creative thinking skills in the second trial had the right criteria. This result was known with a total score of 267 , with an average of 3.14. Therefore, teacher creativity development training succeeds in improving teachers' creative thinking skills in making teaching materials.

The creative thinking skills of teachers in the first trial to trial II have increased with the results of teaching materials that teachers have made in the form of learning videos that teachers have been able to determine teaching materials made based on teaching materials, teachers have also been able to add a variety of materials to the teaching materials in the form of videos made by themselves based on the results of work with learners not only the results of videos from youtube, teachers are also able to add questions/exercises/practices to the teaching materials not only material, teachers in making teaching materials not only focus on what has been learned in training but able to develop themselves according to their thoughts and the teacher not only follow the idea that has been given, designed with his ideas without interference with others.

Analyze the impact of teachers' creative attitudes in creating science thematic teaching materials through Microsoft PowerPoint applications on teacher creativity training development. In the study of teachers' creative attitudes based on questionnaires that have been distributed to teachers or trainees. This observation and research activity concerns teacher creativity training development in the first and second trial stages. The tables and histograms on the teacher's creative attitude are as follows: 
Table 4. Observations of Teachers' Creative Attitudes

\begin{tabular}{|c|c|c|}
\hline \multirow{2}{*}{ Trial } & Average Trial & Criteria \\
\hline I & 3,1 & Good Creative Attitude \\
\hline II & 3,54 & Very Well Creative Attitude \\
\hline Increased & 0,44 & \\
\hline
\end{tabular}

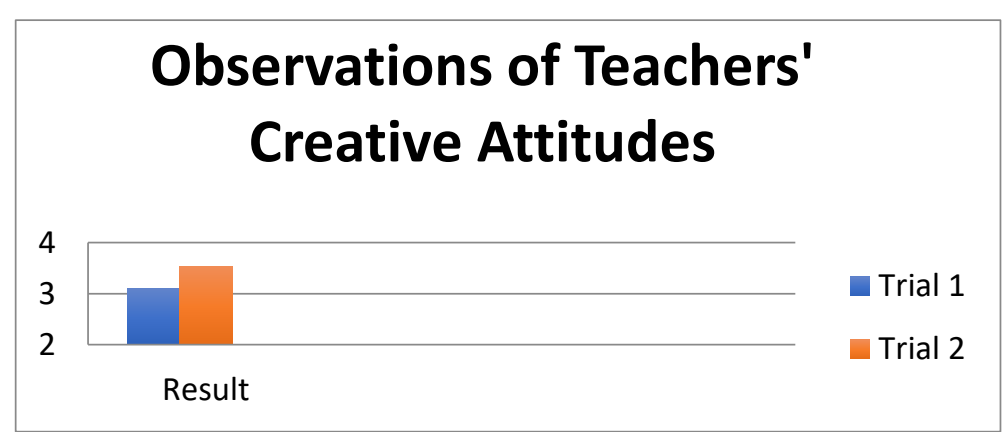

Fig 1. Histogram Of Teacher's Creative Attitude

In table 4.2 and figure 4.4 as above, the teacher's creative attitude has improved. In the trial, I obtained an average of 3.1 with suitable criteria. In the trial, II obtained an average of 3.54 with excellent criteria. The overall average increase from trial I and trial II was 0.44 , so it can be concluded that the teacher's creative attitude has been successful. The teacher's creative attitude has improved in the first trial. Trial II is seen with the teacher's attitude in making teaching materials in the form of exciting learning videos by being able to bring out a positive openness attitude with new experiences. The new experience here is training in teaching materials for teachers, responding well to the attitudes that have been given before and after the training is carried out, teachers can make teaching materials that are fun for learners, utilizing fantasies that are out of mind so that the teaching materials are made interesting, utilizing the creative activities that appear in the learning video, bringing up his ideas instead of the ideas of others, and self-reliance in making his teaching materials.

Analyze teacher responses to teacher creativity development programs in creating science thematic teaching materials using Microsoft PowerPoint applications. This study obtained results based on questionnaires and interviews before teachers/trainees' training that the learning conducted during the Covid-19 pandemic was carried out by online and offline learning. Still, because of the increasing cases, $75 \%$ o, f learning was carried out by online methods, tasks given to students through Whatsapp, google form, and Student Worksheets (LKPD), the form of ringing materials that support learn vital text, PPT, video learning. Teachers gain knowledge on the design of teaching materials other than lectures and training, obtained from $\mathrm{KKG}$ and Webinars. Teachers are still less able to make their own teaching materials, steps to meet the needs of teaching materials most teachers are looking for information. All teachers at SDN 2 Bojanegara want to make their own teaching materials because they are important to support learning and all of them are supported by teaching materials provided by the school in accordance with the students' learning needs. Through training in teaching materials through the Microsoft PowerPoint application, teachers will apply it after the training is ced out so that 
students can understand the material. After the training, the teacher will create materials that are developed according to competencies.

The training was conducted based on questionnaires and interv. Essential felt the impact of the training on making teaching materiafollowings learn at home even if they did not come faceto-face with the teacher. Teachers are happy to attend training and do not feel time-consuming. Training materials need to be supplemented with other training, and the materials delivered are excellent and useful for teachers. This training can be held in other schools, not only at SDN 2 Bojanegara. The factors that support this training activity are the cooperation of all teachers to make their teaching materials. After participating in the training, teachers have made their impressive teaching materials so that learning during the Covid-19 pandemic does not run into obstacles because of all teachers' spirit at SDN 2 Bojanegara.

\section{Results of Improving Teacher Creativity During Training}

Based on the results of questionnaires distributed to teachers/participants to find out how many participants experienced "increased creativity in making teaching materials," then in figure 4.5 showed there was a $100 \%$ increase in "Creative Thinking Skills," $75 \%$ increase in "Creative Attitudes" and 91\% increase in "The role of training in making teaching materials."

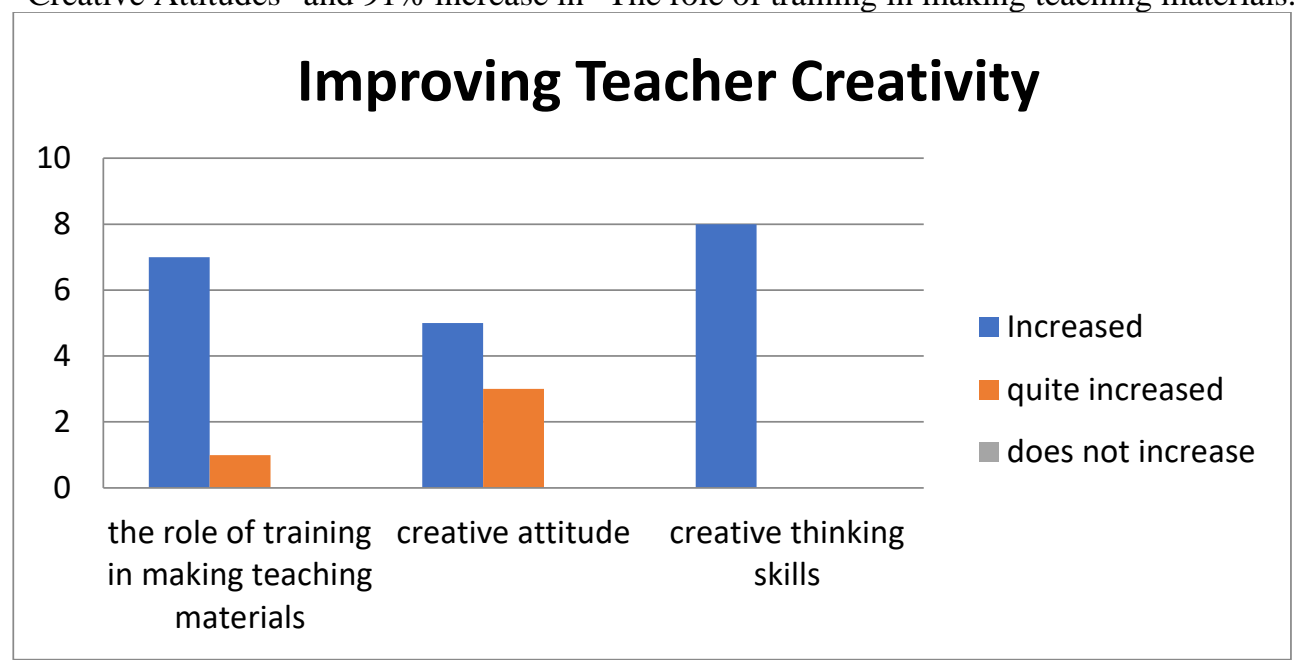

Fig 3. Histograms Increase Teacher Creativity

\section{Material Results During Training}

Based on the results of questionnaires distributed to teachers/participants to find out how many participants feel complete, complete, or incomplete about "teaching materials in the implementation of training/training," then in figure 4.6 shows 8 participants, $100 \%$ feel complete about the material "creative attitude," there are $83 \%$ feel complete about the "role of training in making teaching materials" there are $75 \%$ feel complete about the material "Creative Thinking Skills." 


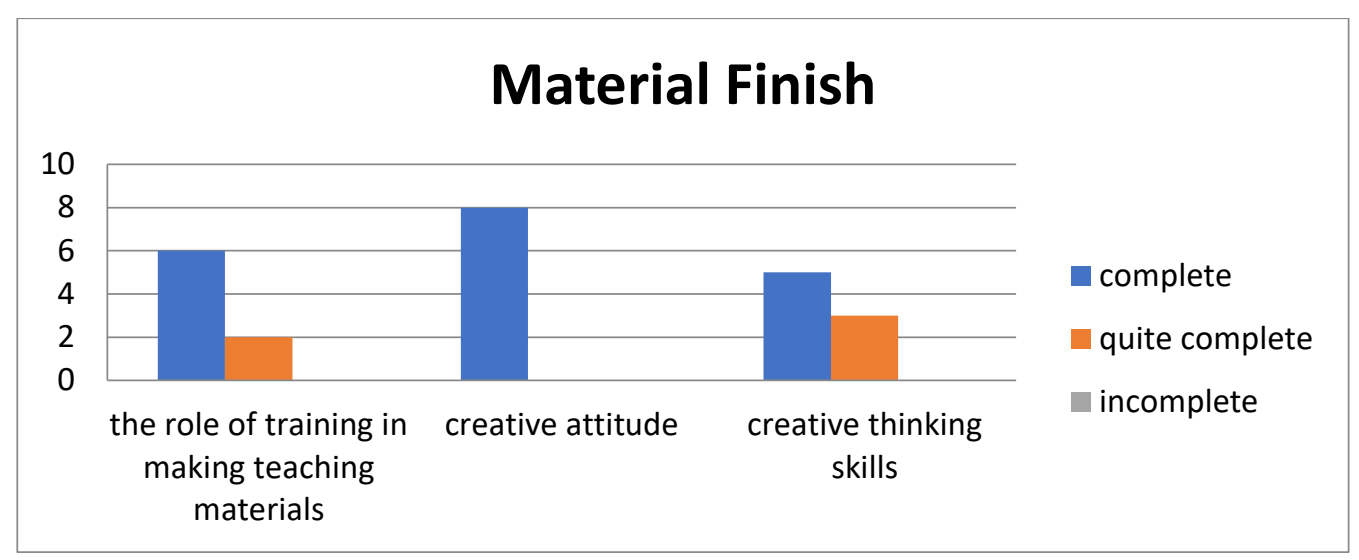

Fig 4. Histogram Of Material Completeness During Training

In line with the research results of Septia Wahyuni et al. (2020) with the title "Training on Creating Interactive Learning Media using Powerpoint." Learning video creation training activities using PowerPoint media were successfully carried out. The desired target in this training activity is achieved. It can be seen from the results of the questionnaire processing given to the trainees at the end of the meeting, showing that $89 \%$ of the trainees were interested in the training provided. Participants gained new knowledge related to learning media that can be used in delivering materials to students. Even participants asked for other pieces of training to help them gain knowledge about other interactive learning media.

Analysis of teacher creativity development training's advantages and limitations in creating science thematic teaching materials through Microsoft PowerPoint applications. Based on responses, responses, and teachers' participation, the advantages of training in developing teacher creativity in making science thematic teaching materials through Microsoft PowerPoint application are the materials obtained in the training according to their needs. The application used is easy to use by teachers. Increase teacher motivation to increase creativity in presenting learning materials online. The training theme is following teachers' needs during the Covid-19 pandemic who need training in making teaching materials. The stylist clearly and intrigued by the training material. Fill the teaching materials according to the ability that is supplied to the teacher.

Limitations on training in developing teacher creativity in making science thematic teaching materials through Microsoft PowerPoint appin training the time given for this training is less long, and some teachers suggest a longer training time so that the material given is more detailed and they have the opportunity to practice it and ask if there are difficulties. This is also supported by the research results conducted by Suana et al. (2018) with the title" Pengembangan Perangkat Flipped Classroom," which states that practical learning tools will make it easier for teachers to manage the classroom appropriately. Thus, the activity of making teaching materials in the form of electronic video can be useful for teachers who need it because it can be accessed online as said by Faruq et al. (2017) with the title "Pengembangan Media Pembelajaran Interaktif Online Pokok Bahasan Barisan Aritmetika Berbantuan Microsoft Visual Basic Fathulloh. From the data exposure above, it can be concluded that teachers' creativity in making teaching materials in the form of learning videos supports the learning process from aspects of creative thinking skills and creative attitudes. Helped by the development training, teacher creativity experienced a significant increase in creativity, making thematic teaching materials of science. 


\section{Conclusion}

From the results of the analysis that has been done by researchers, this study can be concluded that the creative thinking skills of teachers at SDN 2 Bojanegara fall into a suitable category. This is evidenced-based on questionnaires given to 8 respondents, namely participants/teachers who participated in the training from the trial I to trial II experienced an increase in. During the first trial, teacher creativity development training has enough criteria; this result is known with a total score of 206 with an average of 2.42. The observation of teachers' creative thinking skills in the second trial had the right criteria; this result was known with a total score of 267 with an average of 3.14. Therefore, teacher creativity development training succeeds in improving teachers' creative thinking skills in making teaching materials.

The creative attitude of teachers at SDN 2 Bojanegara is a good category. This is proven based on the trial. I obtained an average of 3.1 with suitable criteria. In the trial, II obtained an average of 3.54 with excellent criteria. The overall average increase from the trial I and trial II was 0.44 , so it can be concluded that the teacher creativity development training succeeded in improving teachers' creative attitude in making teaching materials.

So that by implementing training in the development of teacher creativity, there is a transfer of knowledge about understanding and ability in making teaching materials. So that Microsoft PowerPoint applications can help create teaching materials during online learning during this pandemic and learning activities can run well. With hands-on practice and creativity, the results of teaching materials show that teachers are increasingly skilled in making, designing teaching materials in interactive videos that can be used online

Based on the research conducted at SDN 2 Bojanegara, the researchers submitted several suggestions, among others for all parties, especially the stakeholders, it is expected to pay more attention to teachers' creativity in each school. Because with the low creativity of teachers, fast or lamp at the next generation of the nation will be left behind with other nations. For teachers to always develop creative teaching materials to be used in the teaching and learning process. Educational institutions or other institutions should conduct training to increase the creativity of teachers in making teaching materials.

\section{References}

[1] Faruq, F., Dafik, \& Suharto. (2017). Pengembangan Media Pembelajaran Interaktif Online Pokok Bahasan Barisan Aritmetika Berbantuan Microsoft Visual Basic Fathulloh.

[2] Hasbullah. (2008). Dasar-dasar Ilm Pendidikan. Jakarta: PT. Raja Grafindo Persada.

[3] Muflihah, Eneng. (2010). Ilmu Pendidikan Islam. Jakarta: Diadit Media.

[4] Munandar,Utami.(2009). Pengembangan kreativitas anak berbakat. Jakarta:Rineka cipta.

[5] Purwandari, Dyah Ristiana. (2018). Pengembangan Kemampuan Guru Fisika Merancang Praktikum Berbasis Kompetensi Keahlian Melalui Pembekalan Keterampilan Proses Sains dan Kreativitas.

[6] Simo, P., Fernandez, V., Algaba, I., Salan, N., Enache, M., Albareda-Sambola, M., ... \& Rajadell, M. (2010). Video stream and teaching channels: quantitative analysis of the use of low-cost educational videos on the web. Procedia-Social and Behavioral Sciences, 2(2), 2937-2941.

[7] Suana, W., Maulina, H., Fisika, P., \& Lampung, U. (2018). Pengembangan Perangkat Flipped Classroom. Jurnal Pendidikan Fisika Universitas Muhamadiyah Metro, Vol.VI Nom.

[8] Sudjana Nana, Ibrahim. (2009). Penelitian dan Penilaian Pendidikan. Bandung: Sinar Baru Algensindo

[9] Sugiyono. 2016. Metode Penelitian Kuantitatif, Kualitatif dan R\&D. Bandung: Afabeta 
[10] Wahyuni, S., Rahmadhani, E., \& Mandasari, L. (2020). Pelatihan Pembuatan Media Pembelajaran Interaktif dengan Menggunakan Powerpoint. Jurnal Abdidas, 1(6), 597-602.

[11] Warkintin, W., \& Mulyadi, Y. B. (2019). Pengembangan Bahan Ajar Berbasis CD Interaktif Power Point Untuk Meningkatkan Hasil Belajar Siswa. Scholaria: Jurnal Pendidikan Dan Kebudayaan, 9(1), 82-92. 